\section{CULTURA DIGITAL}

\section{O FENÔMENO DOS MEMES}

No contexto da internet, meme é uma mensagem quase sempre de tom jocoso ou irônico que pode ou não ser acompanhada por uma imagem ou vídeo e que é intensamente compartilhada por usuários nas mídias sociais. O termo foi cunhado pelo zoólogo Richard Dawkins em sua obra O gene egoista, de 1976, para fazer uma comparação com o conceito de gene. Assim, para Dawkins, meme seria "uma unidade de transmissão cultural, ou de imitação", ou seja, tudo aquilo que se transmite através da repetição, como hábitos e costumes dentro de uma determinada cultura. Adaptado para a internet, especialmente para as redes sociais, o conceito de meme passa a ser uma "unidade" propagada ou transmitida através da repetição e imitação, de usuário para usuário ou de grupo para grupo.

Essa associaçãa, que resultou no conceito contemporâneo de meme, nasceu no final da década de 1990 , quando um dos criadores da página del.icio.us(umsiteagregadordelinks) criou a página Memepool ("piscina de memes", em tradução livre), que compilava links e outros conteúdos compartilhados pelos usuários na web. No final dos anos 2000, Jonah Peretti, um dos fundadores do portal Huffington Post, gerenciava com alguns amigos a página Contagious Media (algo como mídia contagiante), onde realizava "experimentos" com conteúdos publicados na web. Essas iniciativas culminaram em um "festival de virais", onde a maioria dos participantes se baseava no conceito de Dawkins para remeter a algo que se propagava pela rede.

CONTEÚdO VIRAL Para a pesquisadora em comunicação digital e professora da Faculdade Cásper Líbero, Janaíra França, os memes são mais antigos que a própria cultura digital, mas encontraram nela solo fértil para se expandir devido à capacidade de propagação. "A facilidade com que esses canais permitem que uma dada informação seja repassada adiante é a força motriz da linguagem dos memes", comenta. A propagação se dá, segundo França, por uma série de fatores inerentes ao meio digital. "Os memes são apropriações temáticas que vão desde o humor sobre amenidades até assuntos como política e economia, e que têm, na maioria das vezes, mensagens de compreensão fácil e rápida. Some a isso a facilidade de publicação e o compartilhamento, sobretudo pelas redes sociais, e teremos a viralização do conteúdo”, complementa a professora.

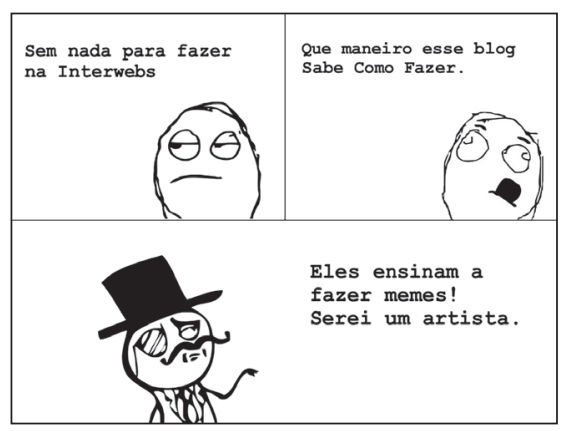

Quase tudo pode virar um meme: ideias, filmes, falas, costumes, futebol e até a política
Também emprestado da biologia, o termo viralização remete a algo que se espalha de maneira contagiosa, infectando e se disseminando na internet. Essa talvez seja uma das características mais marcantes do fenômeno meme na cultura digital, mas não é a única. Assim como na concepção original de Richard Dawkins, um meme precisa evoluir para conseguir se propagar na rede, já que não é fácil conquistar a atenção dos usuários nesse emaranhado de likes, shares e selfies.

Segundo a professora e jornalista especializada em marketing, Silvia Ferreira, da Universidade Bilac, em São José dos Campos (SP), na cultura digital os memes devem se adaptar aos mais diferentes contextos para fisgar a atenção das pessoas. "Um meme pode ser tudo, menos estático. Se não inovar na mensagem ou na forma, estará fadado ao esquecimento", diz. Ferreira lembraque atéem ambientes corporativos podemos ver essa adaptação. "Muitas empresas e instituições já possuem departamentos de comunicação que se encarregam de produzir memes. Se não entregarem algo novo, adaptado ao público, o meme pode ser subtraído da rede e sua evolução cessará”, enfatiza. $\mathrm{O}$ processo adaptativo do

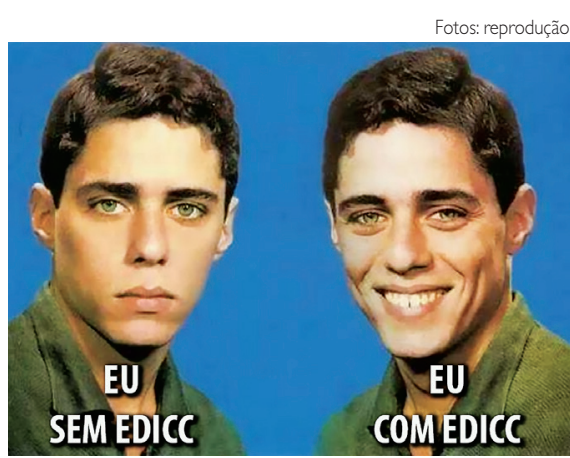

Meme utilizado para um evento que ocorreu na Unicamp. A montagem e reuso de imagem são fortes características dos memes 
meme leva em consideração, segundo França, a própria audiência para quem essa mensagem se dirige. "Eles são um tipo de linguagem que tenta expressar o que a audiência digital tem interesse em determinado momento. Deve ser lúdico, divertido", coloca.

FORMAS HÍBRIDAS Os memes podem ter como origem fontes diversas: discursos, falas, costumes, erros de arbitragem no futebol, furos jornalísticos, fatos engraçados, personagens políticos e até notícias de economia. Tudo que pode gerar interesse em uma dada rede de usuários pode ser fonte para criação de um meme. Os formatos também variam, desde imagens simples, montagens propositalmente grotescas, quadrinhos e tirinhas. A reutilização é uma característica marcante de um meme, pois nem sempre regras, como direitos autorais, são respeitadas. $\mathrm{Na}$ verdade, a apropriação "indevida" e a releitura de uma imagem de um filme, um logotipo de uma empresa, uma fotografia etc. é parte fundamental da construção de um meme. Para Janaíra França, memes são códigos de uma linguagem importante da cultura digital e parte intrínseca desse ambiente. "Tentar barrar um meme ou desconstruí-lo por julgá-lo inadequado, por exemplo por usar uma imagem sem autorização, pode dar mais força a ele", comenta. O processo evolutivo e a capacidade de assumir os mais variados formatos é o que tornam o meme algo tão único, próprio do ambiente digital, um cenário igualmente em constante mudança.

Ton Torres

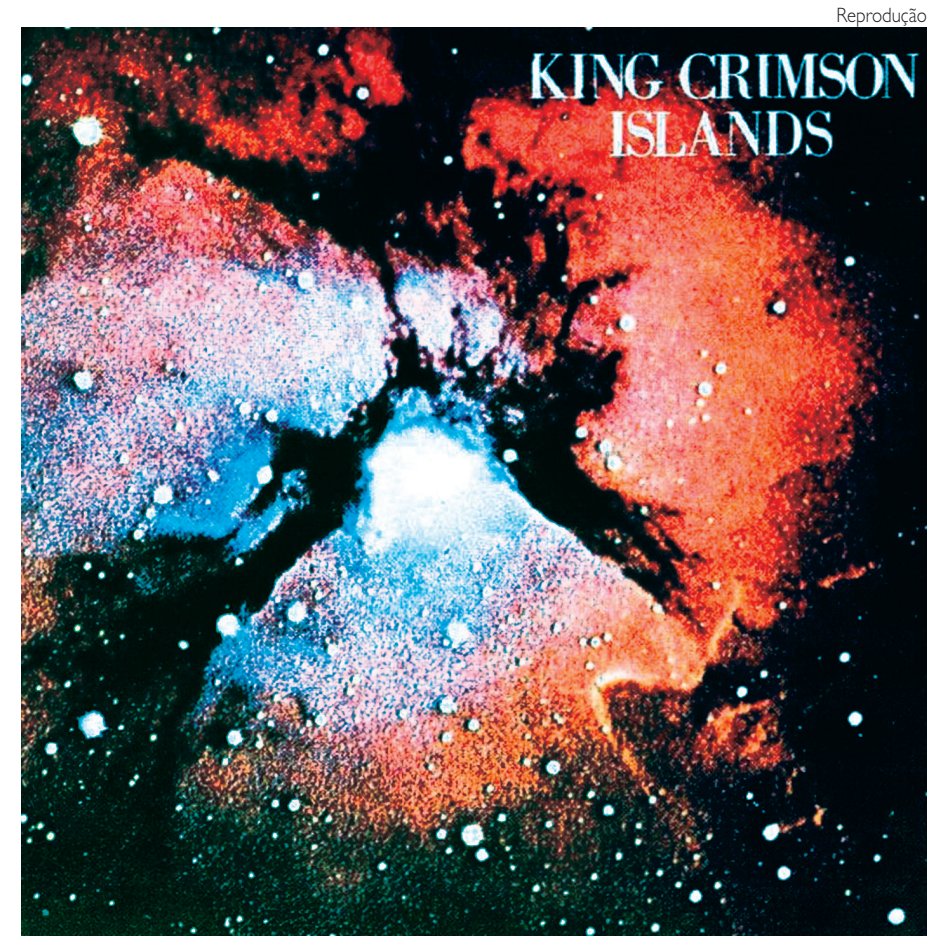

Viagens espaciais são tema constante no rock do final dos anos 1960

\section{CIÊNCIA}

\section{ROCK PARA}

\section{BALANÇAR O ENSINO DA FÍSICA E DA ASTRONOMIA}

Pink Floyd, Led Zeppelin, Queen, Black Sabbath e David Bowie não são comuns no repertório musical das novas gerações, mas ainda fascinam aqueles que cresceram com esses artistas subversivos que questionaram da Guerra Fria até a chegada do homem à Lua e contestavam os valores conservadores da sociedade, sobretudo no final dos anos 1960. Mas, se a questão for o ensino da física e da astronomia, Emerson Ferrei- ra Gomes, doutor em educação pela Universidade de São Paulo (USP), aposta que o mais puro rock'n roll é capaz de inspirar o debate em sala de aula e ainda enriquecer a cultura musical.

A tese de Gomes, defendida em abril deste ano, analisa nove canções de rock, dentre as quais duas brasileiras: "Viagens espaciais, comunicações e observação do céu”, de Os Mutantes, e "Órbita dos planetas, imagem da ciência", dos Novos Baianos. As músicas foram trabalhadas com alunos de graduação e do ensino médio e com professores da educação básica, de modo a contemplar diferentes níveis da educação.

Apesar da maioria das letras ser em inglês, Gomes e seus monitores trabalhavam com as canções traduzidas, fornecendo seus contextos históricos, seguidos de um debate em grupo sobre a letra, melodia e 